\title{
O PROJETO DE DRENAGEM EM PAVIMENTOS ASFÁLTICOS: CONSERVA O REVESTIMENTO, PREVINE ACIDENTES E DANOS AO MEIO AMBIENTE
}

\author{
THE DRAINAGE PROJECT IN ASPHALT FLOORS: CONSERVES COATING, \\ PREVENTS ACCIDENTS AND DAMAGE TO THE ENVIRONMENT
}

\author{
Alyson Freitas Pinheiro ${ }^{1}$ \\ Fernanda Martins Coutinho ${ }^{2}$ \\ Mônica Fernandes Ferreira ${ }^{3}$
}

RESUMO A construção civil é um dos ramos mais importantes de um país, a vida útil das rodovias usadas para o transporte de cargas e pessoas, é um ciclo repetitivo, desse modo é necessário olharmos para a conservação das rodovias através de métodos que forneça condições apropriadas para o tráfego. Este artigo explana sobre a importância do sistema de drenagem rodoviária. Nessa perspectiva a pesquisa tem como objetivo de estudo principal analisar de forma bibliográfica a importância do sistema de drenagem nas rodovias destacando os tipos de drenagens e seus principais dispositivos.

Palavras-chave: Construção Civil. Rodovias. Drenagem.

ABSTRACT: Civil construction is one of the most important branches of a country, the useful life of the highways used for the transportation of cargo and people, is a repetitive cycle, so it is necessary to look at the conservation of the highways through methods that provide appropriate conditions for traffic. This article explains the importance of the road drainage system. In this perspective, the research has as main objective to analyze, in a bibliographic way, the importance of the drainage system on the highways, highlighting the types of drainage and its main devices.

Keiywords: Civil construction. Highways. Drainage.

\section{I- INTRODUÇÃO}

Em uma construção rodoviária, a drenagem é um elemento indispensável para assegurar a conservação da rodovia, prevenindo acidentes decorrentes do acúmulo de água (aquaplanagem) desse modo é essencial que as rodovias sejam seguras para o tráfego de

\footnotetext{
Graduando em Engenharia Civil, Faculdade Aldete Maria Alves/FAMA. Iturama/MG. alissonpinheiro456@gmail.com

2 Graduando em Engenharia Civil,Faculdade Aldete Maria Alves/FAMA. Iturama/MG. fernandaeng3o@outlook.com

3 Docente Especialista da Faculdade Aldete Maria Alves/FAMA, Iturama/MG. eng.monicafernades@gmail.com
} 
veículos. Por isso a drenagem é a principal responsável por evitar o acúmulo de água que danifica a estrutura do pavimento, provocando acidentes. Portanto um sistema de drenagem bem projetado, construído e conservado, garante a segurança dos usuários da via, reduzindo consideravelmente o número de acidentes, e também aumentando a durabilidade da rodovia, dos elementos estruturais e da integridade dos taludes de corte e aterro.

São fatores de deterioração do pavimento:

- Erro de projeto e construção;

- Fadiga e oxidação;

— Tráfego e condições climáticas;

- Falta de manutenção;

- Materiais inadequados.

É importante manter o pavimento com um bom sistema de drenagem, em caso contrário, sua vida útil pode ser reduzida em até 70\%.

\section{2- $\quad$ A IMPORTÂNCIA DO SISTEMA DE DRENAGEM RODOVIÁRIA}

O presente artigo tem como finalidade expor de forma bibliográfica a importância do sistema de drenagem rodoviária e os impactos ambientais gerados decorrentes da não implantação de um sistema adequado. É de suma importância manter o pavimento com um bom sistema de drenagem, caso contrário, a vida útil da via pode ser reduzida em até 70\%. Um pavimento mau drenado pode custar o dobro de um pavimento com drenagem eficiente.

Para entendermos a importância de um sistema de drenagem na construção civil devemos primeiramente compreender que a água presente no planeta está em constante transformação devido o ciclo hidrológico. Ao iniciar a evaporação boa parte vai até atmosfera e se condensa provocando a precipitação (chuva), nesse processo parte é evaporada e o restante escoa pela vegetação e superfície, penetrando até a crosta e atingindo o lençol freático. A parte que permanece na superfície busca-se se juntar aos rios e nascente. (ROCHA,2019 apud ALMEIDA, 2007).

A conservação da via é o melhor investimento possível, porque não só garante o investimento inicial na construção, mas também reduz o custo operacional, 
proporcionando uma maior vida útil do pavimento e dos veículos. Todos os pavimentos necessitam de manutenção para evitar possíveis fissuras, depressões e outros tipos de falhas que são indícios de desgaste do pavimento asfáltico. Uma forma de conservação preventiva é manter a limpeza das obras de drenagem, se elas funcionam corretamente, evitamos algumas das principais causas de danos nos pavimentos. A drenagem é um fator de grande importância na atuação da maioria dos elementos de uma estrada.

Imagem I. Manutenção e conservação da rodovia

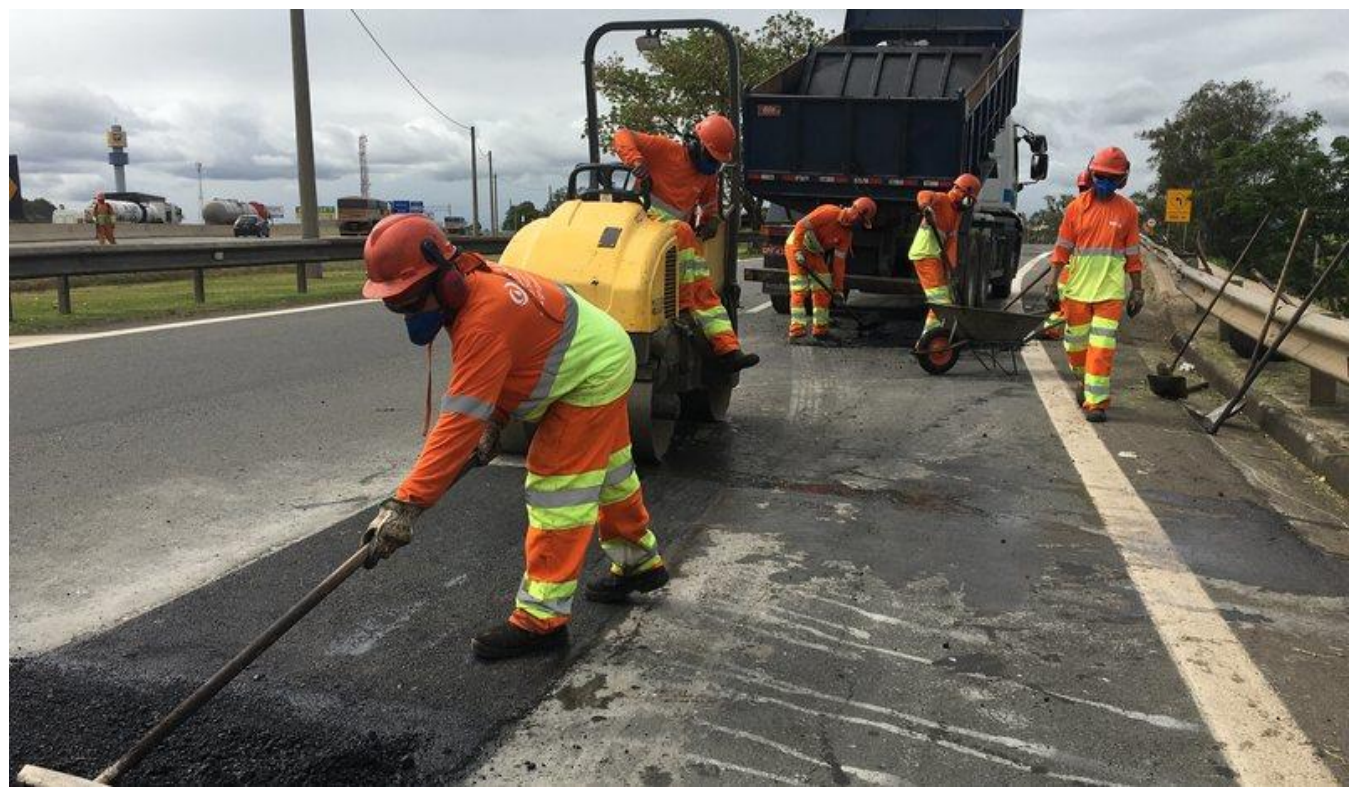

Fonte via: Disponível em<https://grupoatual.com.br/manutencao-e-conservacao-de-rodovias/ > Acesso em 25 de abril de 2021.

\section{3- PROBLEMAS QUE PODEM AFETAR OS USUÁRIOS DA VIA, PELO SISTEMA DE DRENAGEM INADEQUADO OU INEFICIENTE}

O principal dever da drenagem é conduzir corretamente a água, conservando as características de resistência do subleito, da sub-base e da base do corpo estradal, garantindo a vida útil da estrada com maior durabilidade, e também, evitando o acúmulo de água na superfície da rodovia bem como o rebaixamento do lençol freático.

Vale destacarmos que, devido à grande complexidade do sistema, é necessário realizar trabalhos preventivos para identificação de possíveis problemas, como o surgimento de erosão de grande dimensão.

Com a conservação rotineira adequada, mais a execução do reforço estrutural do pavimento, devida e adequadamente projetado e bem executado, uma rodovia pavimentada 
nunca se deteriorará até chegar ao mau estado, quando é necessária a restauração ou mesmo a reconstrução do pavimento (DNIT, 2005, p. 312).

A água pode vir acarretar sérios problemas às estradas e rodovias, como a deterioração da estrutura do piso, escorregamento, quebra de aterros e também dos taludes. Para impedir danos desta natureza, a engenharia civil faz uso do sistema de drenagem, que tem como função principal destinar adequadamente a água que escoa pelas vias, instalando canaletas, bueiros, saídas d'água, sarjetas e etc.

Podemos também destacar que a água é o maior inimigo dos pavimentos asfálticos, podendo atingir a sua base e/ou sub-base, o que ocasiona uma redução em sua capacidade de suporte, bem como ao reduzir a proteção da camada superficial, pode abrir caminhos para novas infiltrações, agravando o problema dando origem a um círculo vicioso. Dentre outros acidentes ou problemas provocados pela ação da água, tem-se o escorregamento e erosão de taludes, o rompimento de aterros, o entupimento de bueiros, a queda de pontes, a diminuição da estrutura do pavimento, a variação de volume de solos mais expansivos, a destruição do pavimento pela pressão hidráulica, a oxidação e envelhecimento prematuro dos asfaltos, o que pode ser evitado com a utilização de alguns dos vários dispositivos existentes, tais como, a drenagem superficial, drenagem do pavimento, drenagem profunda e também drenagem de transposição de talvegues.

\section{4- TIPOS DE DISPOSITIVOS DE DRENAGEM RODOVIÁRIA}

Os dispositivos de drenagem têm a finalidade de desviar a água de sua plataforma.

Tipos de drenagem:

Superficial

Transposição de Talvegues

Pavimento

\section{I - DRENAGEM SUPERFICIAL}

A drenagem superficial de uma rodovia tem como objetivo interceptar e captar, conduzindo ao deságue seguro, as águas provenientes de suas áreas adjacentes e aquelas que se precipitam sobre o corpo estradal, resguardando sua segurança e estabilidade. 
Para um sistema de drenagem superficial eficiente, utiliza-se uma série de dispositivos:

\section{DISPOSITIVOS DE DRENAGEM SUPERFICIAL}

I. Valetas de proteção de corte e aterro;

2. Valeta do canteiro central;

3. Sarjetas de aterro;

4. Sarjetas de corte;

5. Bueiros de greide;

6. Escalonamento de taludes;

7. Valetas de proteção de corte e aterro:

8. Saídas d'água;

9. Descidas d'água;

Io. Caixas coletoras;

II. Dissipadores de energia;

I2. Corta-rios.

\section{I.I Valeta de proteção de corte e aterro}

É um dispositivo de segurança que evita a chegada da água ao talude estrutural do pavimento que pode vir a provocar danos ao corpo estradal.

Valetas de proteção de corte e aterro - têm a finalidade de evitar que as águas procedentes das encostas de montante atinjam a rodovia, evitando erosões e desestabilização do talude de corte e aterro, garantindo sua estabilidade. A valeta pode ter a forma retangular ou trapezoidal, sendo que a trapezoidal possuiu uma melhor eficiência hidráulica. Recomenda-se que, sua localização seja a uma distância mínima de $3.00 \mathrm{~m}$ da linha de offset (crista do corte e/ou pé do aterro), que o material removido na escavação seja, removido e transportado até um local adequado. 
Imagem 2. Valeta de proteção de aterro

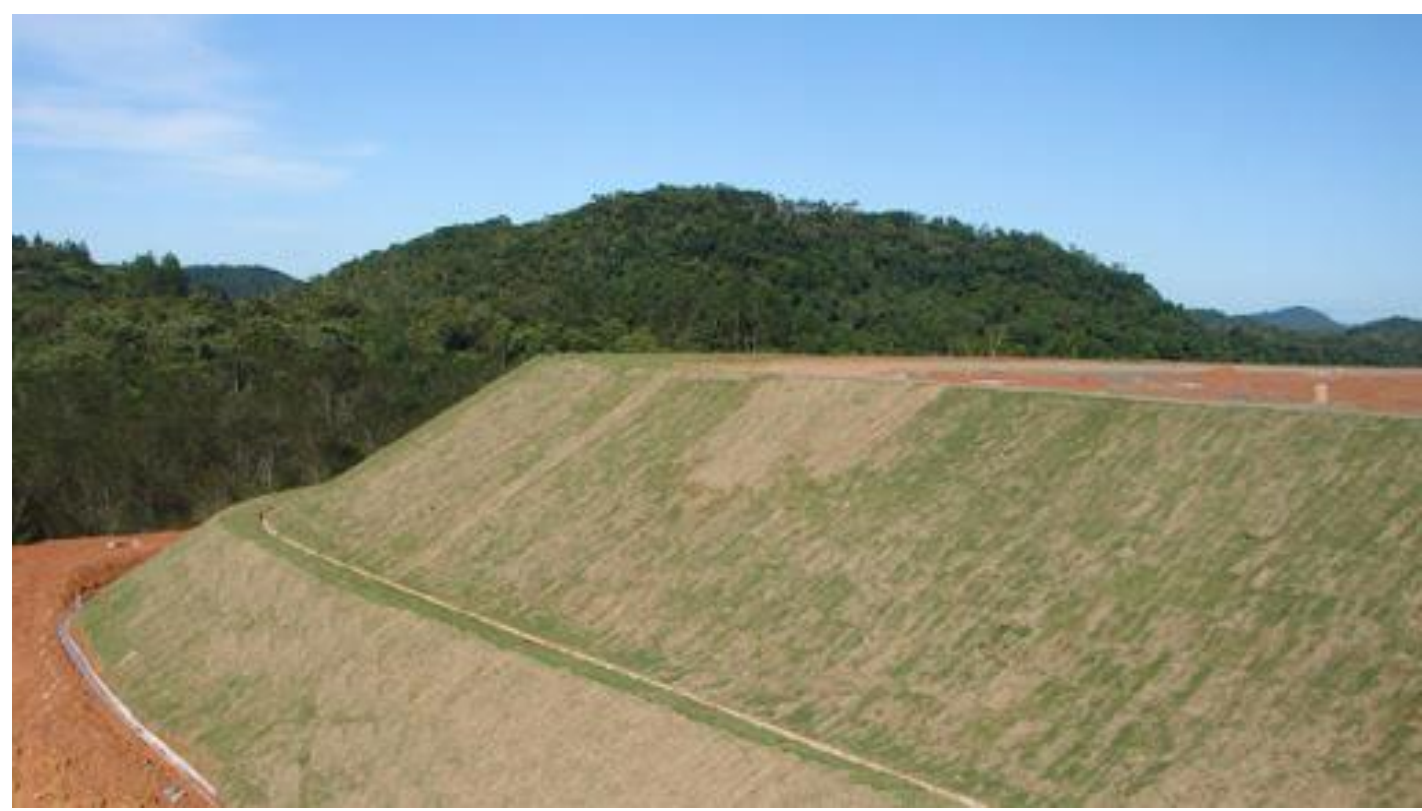

Fonte via: Disponível em < http://vogelsangerempreendimentos.com.br/site/servicos/servicoscomplementares/ > Acesso em or de maio de 2021.

\subsubsection{Valeta do canteiro central}

Podemos definir valeta do canteiro central como um obstáculo, construído como um separador de duas pistas, tendo sua substituição por sinalização viária, que é o caso das pistas simples. Além de ser separador das pistas de rolamento, também possui função muito importante na segurança e drenagem.

$\mathrm{Na}$ drenagem os canteiros centrais por meio das valetas e da própria filtração do solo, contribuem para drenar todo e qualquer líquido no corpo estradal, assim evitando acidentes em razão da perca do atrito dos pneus com o pavimento. Vale ressaltar que os canteiros centrais devem possuir uma inclinação mínima em suas respectivas bordas, para que a drenagem possa ser eficiente para as valetas.

A valeta do canteiro central direcionará as águas ao longo da rodovia até chegar a caixa coletora do bueiro de greide, onde deve desaguar no canal mais profundo do leito. Com relação a segurança, os canteiros centrais ajudam, sendo uma área de refúgio para os motoristas que perdem a atenção, assim evitando que em casos de pista dupla o motorista invada a outra pista. Rodovias que possuem o canteiro central a uma largura apropriada, a ocorrência de colisões frontais é mínima. 
Imagem 3. Valeta do canteiro central

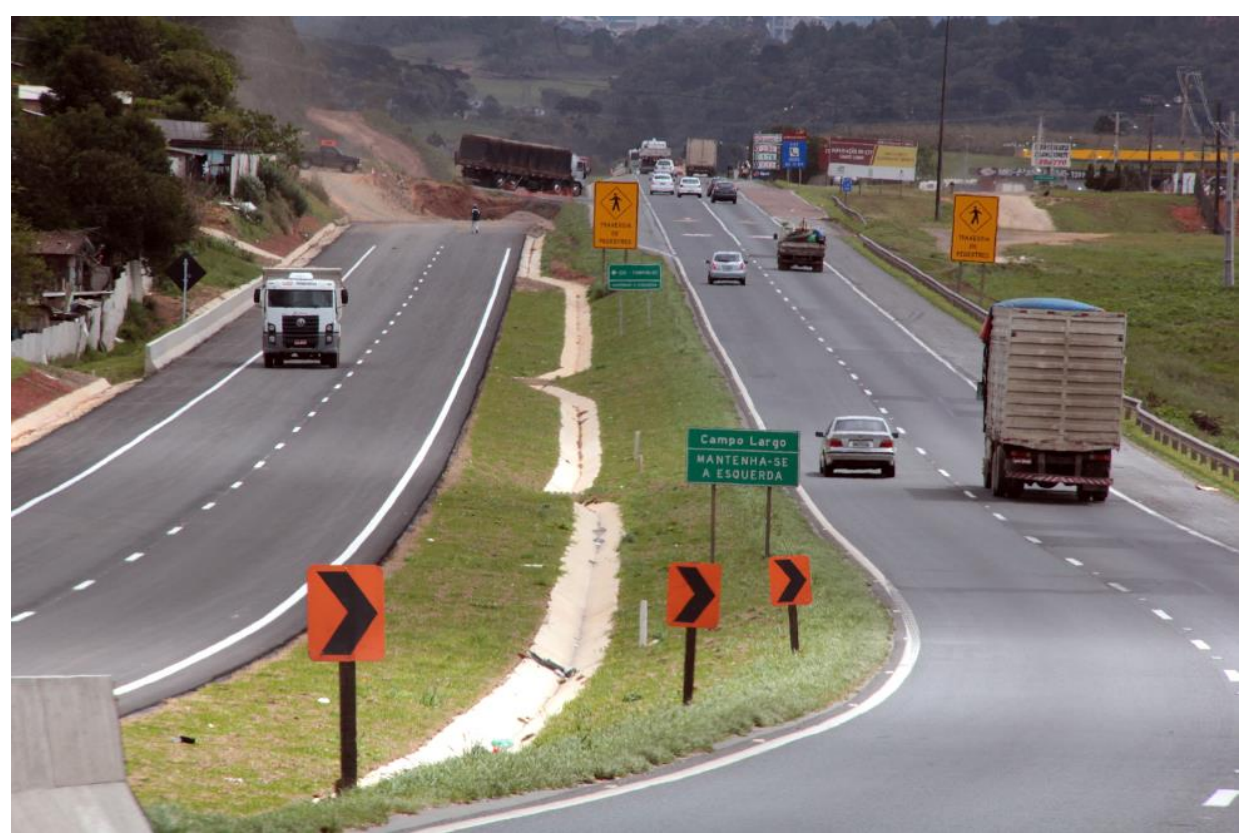

Fonte via: Disponível em <https://bityli.com/MkJnr > Acesso em or de maio de 202I.

\subsubsection{Sarjetas de aterro}

Tem como objetivo captar as águas precipitadas sobre a plataforma, de modo a impedir que provoquem erosões na borda do acostamento ou no talude do aterro, conduzindo-as ao local de deságue seguro. Devem ser construídas a uma distância entre dois a três metros no pé do talude de aterro, para não atingir o mesmo, o material resultante da escavação retirado, deve ser posto entre a valeta e o pé do talude de aterro e apiloado manualmente, com o objetivo de suavizar a interseção das superfícies do talude e do terreno natural. Podendo apresentar seções trapezoidais ou retangulares.

A sarjeta de aterro deve ser posicionada na faixa da plataforma próxima ao acostamento. A seção transversal pode ser trapezoidal, triangular, retangular e etc., isso vai de acordo com a natureza e categoria da rodovia. Vale destacar que devem-se ter critérios bem definidos para a escolha de sua seção transversal. Sendo um dispositivo que pode vir a comprometer a segurança do tráfego, devem ser tomados devidos cuidados quanto ao posicionamento e a seção transversal utilizada, de modo que deve garantir a segurança dos veículos em circulação. 
As sarjetas de aterro utilizam materiais diversos em seu revestimento, que dependendo do tipo do solo, podem ser: concreto de cimento; concreto betuminoso; solo betume; solo cimento; solo (DNIT, 2006).

\section{Imagem 4. Sarjeta de aterro}

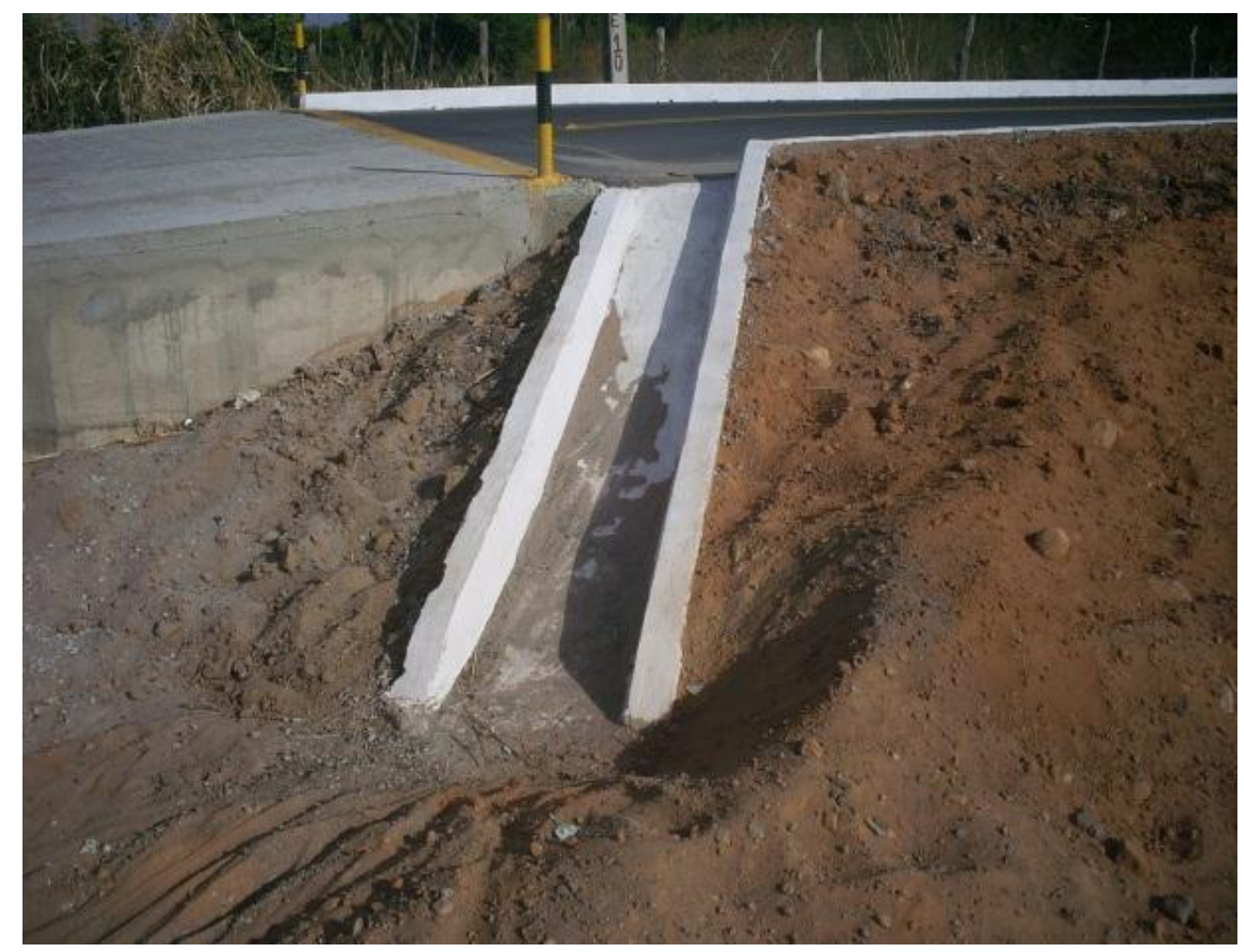

Fonte via: Disponível em <https://bityli.com/rUKok> Acesso em 02 de maio de 2021.

\subsubsection{Sarjetas de corte}

São dispositivos de drenagem construídos lateralmente às pistas de rolamento com o objetivo de captar as águas que se precipitam sobre a plataforma e taludes de corte e conduzi-las, longitudinalmente à rodovia, até o ponto de transição entre o corte e o aterro, de forma a permitir a saída lateral para o terreno natural ou para a valeta de aterro.

Vale destacar que a seção triangular é um tipo bem aceito, pois, além de apresentar uma razoável capacidade de vazão, tem a seu favor a importante vantagem da diminuição dos riscos de acidentes, uma vez que, se um veículo sai da pista de rolamento para a sarjeta, seu formato possibilita que o condutor consiga controlar o veículo retornando para a pista. 
Imagem 5. Sarjeta de corte

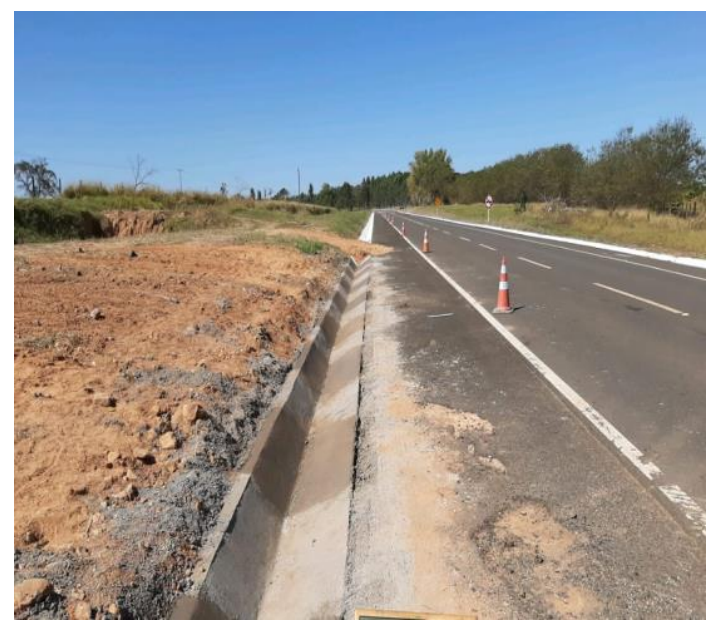

Fonte via: Disponível em < http:// https://

https://twitter.com/DNIToficial/status/1 288165479245385728/photo/3 > Acesso em 02 de maio de 2021
Imagem 6. Falta da Sarjeta

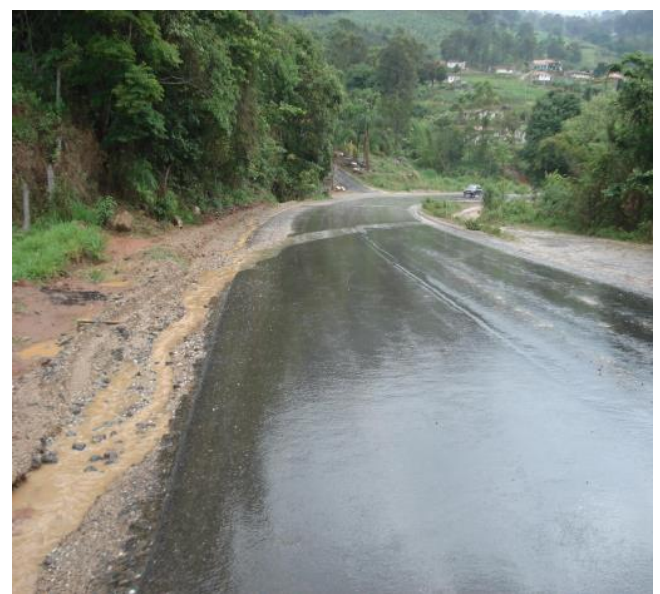

Fonte via: Disponível em < http://www.assender.com.br/wpcontent/uploads/2015/09/marcosjabor.pdf > Acesso em 02 de maio de 2021.

\subsubsection{Bueiros de Greide}

São bueiros nos quais a entrada d'água é feita através de caixas coletoras, sendo usados para permitir a transposição de fluxos d'água coletados através de dispositivos de drenagem superficial. Esse dispositivo pode ser construído tanto transversalmente como longitudinalmente em relação à rodovia, e quanto ao material utilizado para sua confecção pode ser concreto ou metálico.

Os Bueiros podem ser classificados:

a) quanto à forma da seção:

Tubulares, quando a seção for circular;

Celulares, quando a seção for retangular;

Especial, quando a seção for em arco, elíptica, etc.

b) quanto ao número de linhas:

Simples, duplos, triplos, etc.

c) quanto ao tipo de material:

$>$ Concreto simples; 
$>$ Concreto armado;

$>$ Chapas metálicas corrugadas.

Imagem 6. Bueiro de greide de concreto

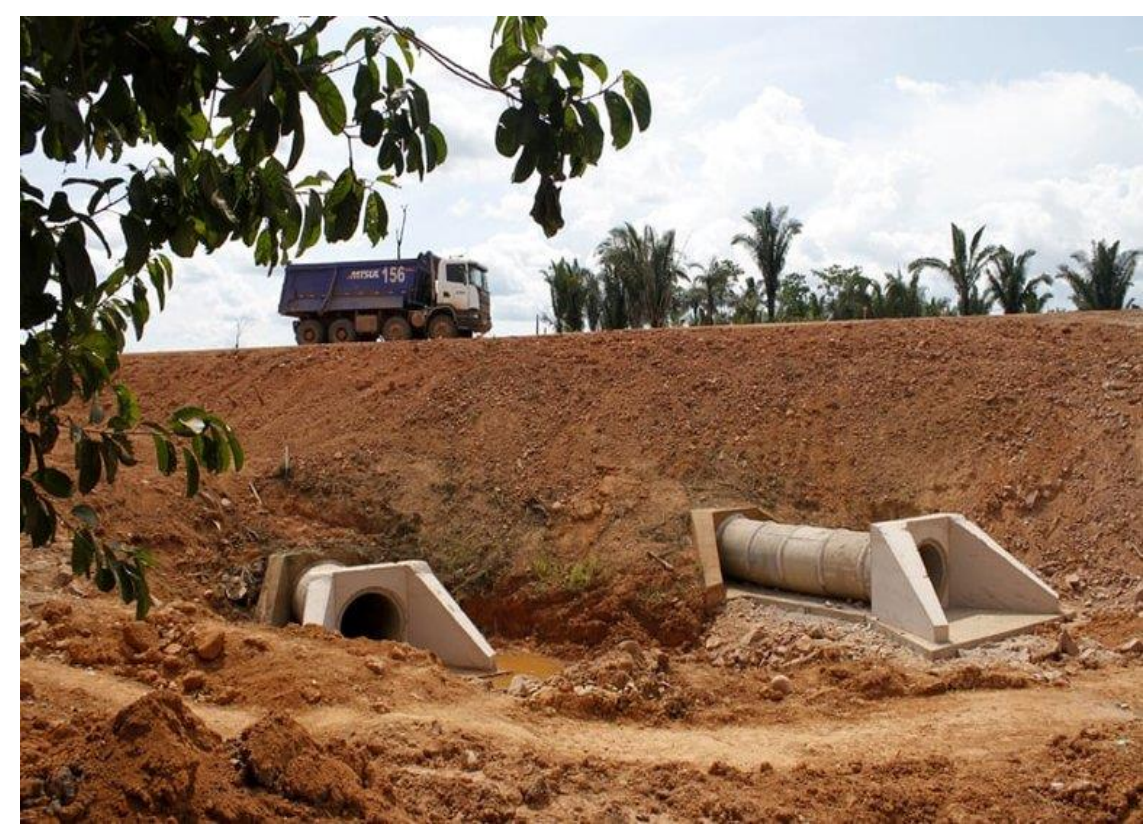

Fonte via: Disponível em < http:// https://www.gentedeopiniao.com.br/colunista/jose-carlos-sa/elevandoo-greide-por-jose-carlos-sa $>$ Acesso em 24 de maio de 2021.

Imagem 7. Bueiro metálico

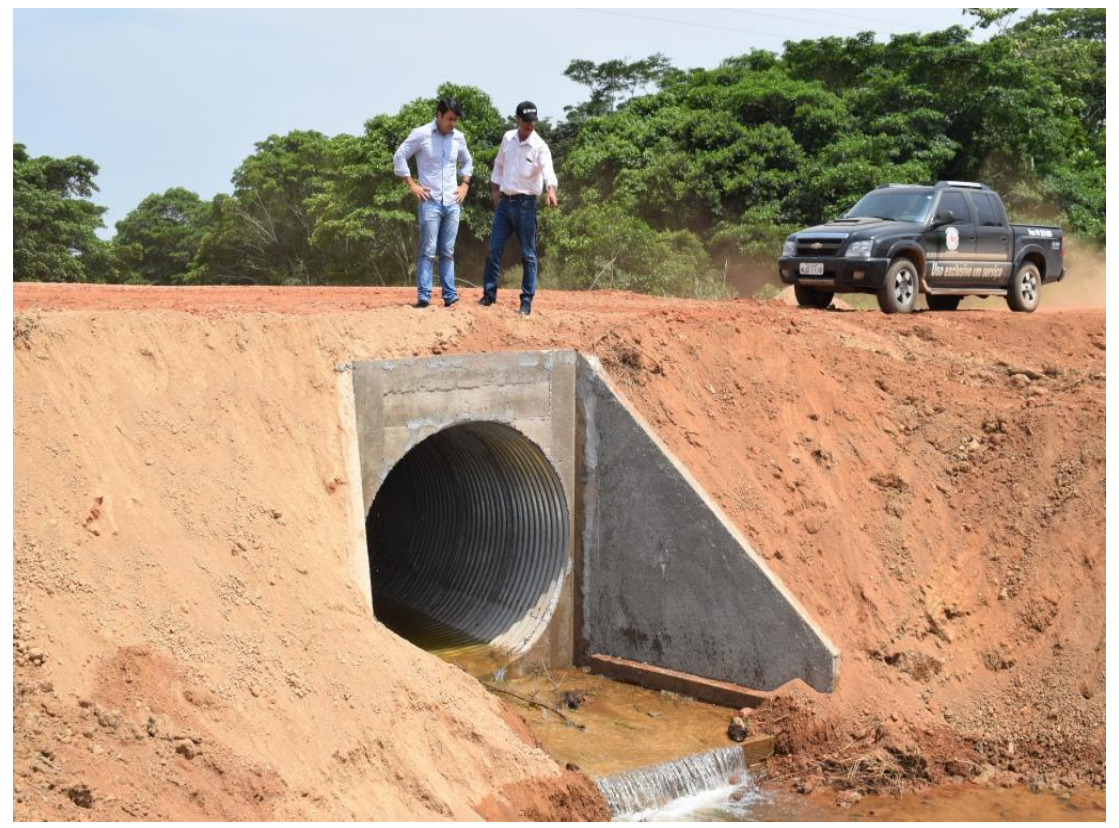

Fonte via: Disponível em em < https://cutt.ly/MnYK25q $>$ Acesso em 30 de maio de 2021. 


\subsubsection{Escalonamento de Taludes}

Podemos definir como talude uma superfície inclinada que demarca um maciço terroso ou rochoso, ou seja, talude é qualquer tipo de terreno natural, artificial ou inclinado que serve como sustentação do solo. Tem como principal objetivo evitar que as águas precipitadas sobre a plataforma e sobre os taludes, atinjam, através do escoamento superficial, uma velocidade acima dos limites de erosão dos materiais que os compõe.

Podemos distinguir os taludes em dois tipos:

- Talude natural - é aquele que foi formado naturalmente pela natureza, pela ação geológica ou pela ação das intempéries (sol, chuva, vento).

— Talude artificial: é aquele que foi construído por intervenção do ser humano.

É possível encontrar taludes artificiais em minas a céu aberto, nas barragens de reservatório de água, nas laterais de estradas e ruas, na escavação de uma vala para assentamento de tubo de água e até nos fundos das casas construídas em local em aclive (terreno subindo) ou declive (terreno descendo).

Os taludes têm importantes funções como:

- Para barragem, quando são construídos com a finalidade de barrar um rio e formar um reservatório.

- Para evitar a queda de blocos, quando são essenciais para evitar quedas e rolamentos de blocos que acarretariam uma grande instabilidade no terreno.

- Para manutenção e preservação dos terrenos, em que os processos erosivos causados pelas águas pluviais podem ser solucionados pelos taludes.

- Para reforçar o solo e evitar problemas de erosão, introduzindo elementos resistentes através de taludes de escavação.

Em casos de taludes instáveis, recorrentes a escorregamentos principalmente em períodos de chuvas, onde acontece uma intensa precipitação, que denota a saturação do solo e a sobrepressão do solo internas, sendo a principal causa de escorregamentos. Podendo ocasionar sérios riscos a integridade física e as vidas humanas das pessoas que trafegam em suas proximidades, o avanço de possíveis erosões sobre o talude, compromete a estabilidade do mesmo ao longo dos anos. 
Imagem 8. Escalonamento do talude

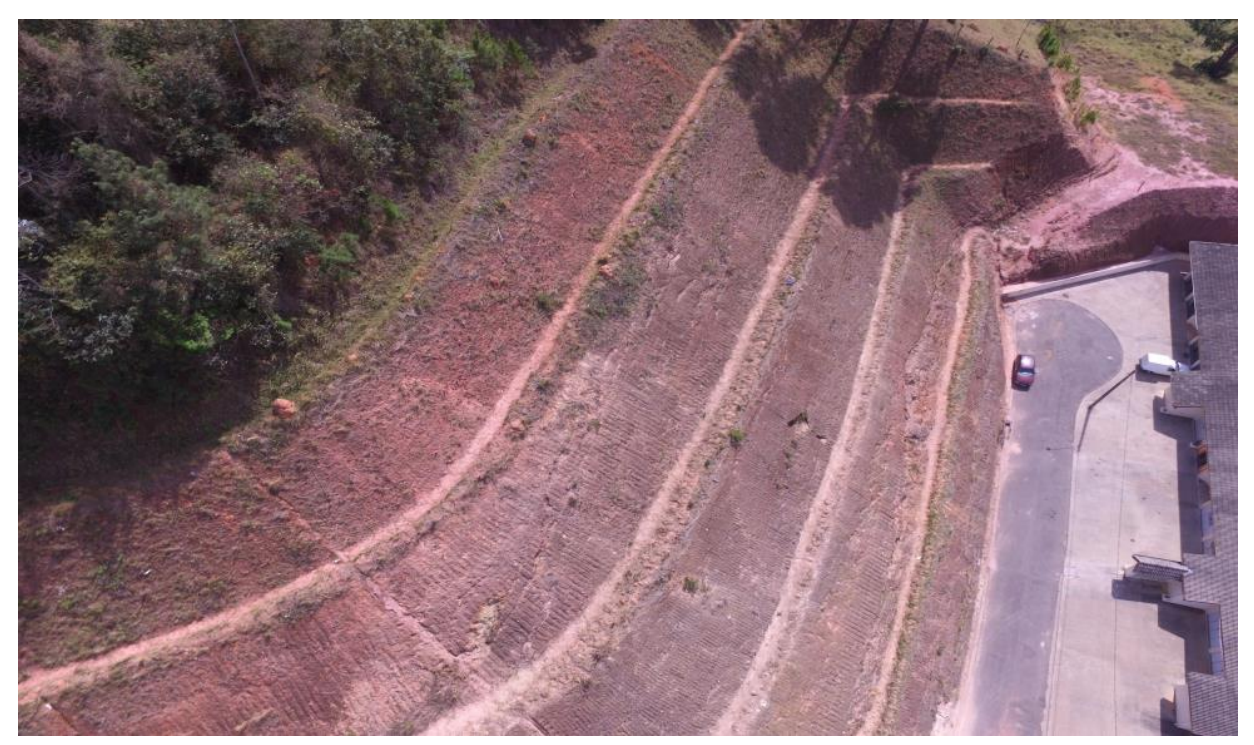

Fonte via: Disponível em < https://www.engevant.com.br/taludes/> Acesso em 25 de maio de 2021

Imagem 9. Escalonamento do talude frontal

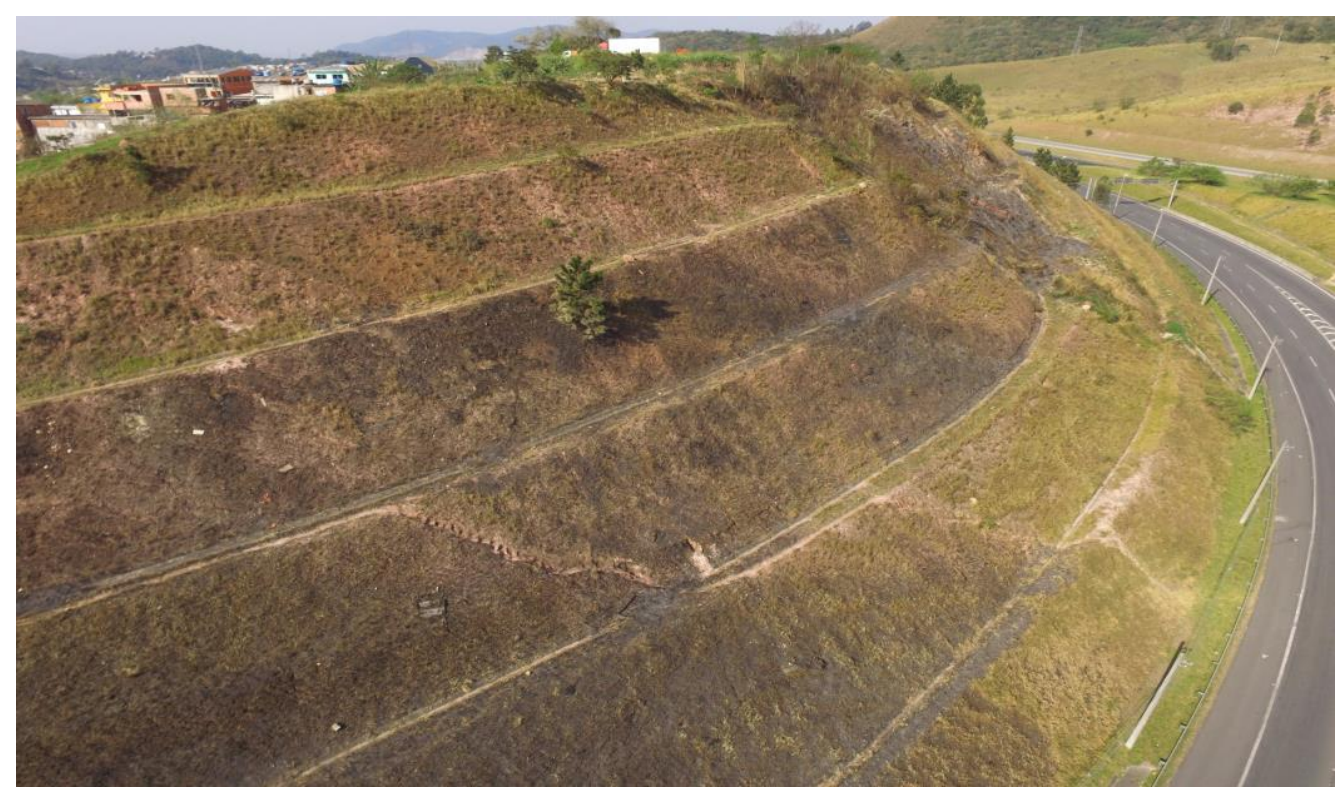

Fonte via: Disponível em < https://www.engevant.com.br/taludes/> Acesso em 25 de maio de 2021.

\subsubsection{Valetas de Proteção de Corte}

Valetas de Proteção de Corte (VPC) tem como finalidade impedir que a água que vem da encosta chegue ao pavimento asfáltico, assim evitando a desestabilização e a erosão do 
talude. Sua forma é trapezoidal, as valetas com a forma trapezoidais são as mais recomendadas por apresentar uma maior eficiência hidráulica. Tendo como recomendação uma distância mínima entre 3,o metros da crista do corte.

Por fim, tendo finalidade o escoamento da água para um bueiro ou linha d'água que esteja mais próximo. Por motivo de facilidade de execução, a seção a ser adotada nos cortes em rocha deve ser retangular. É importante executar as valetas de proteção de corte antes da execução de hidrossemeadura, para evitar retrabalho e gastos desnecessários com serviços ambientais. A figura abaixo demonstra uma valeta de proteção de corte trapezoidal.

Imagem ı. Valeta de proteção de corte trapezoidal

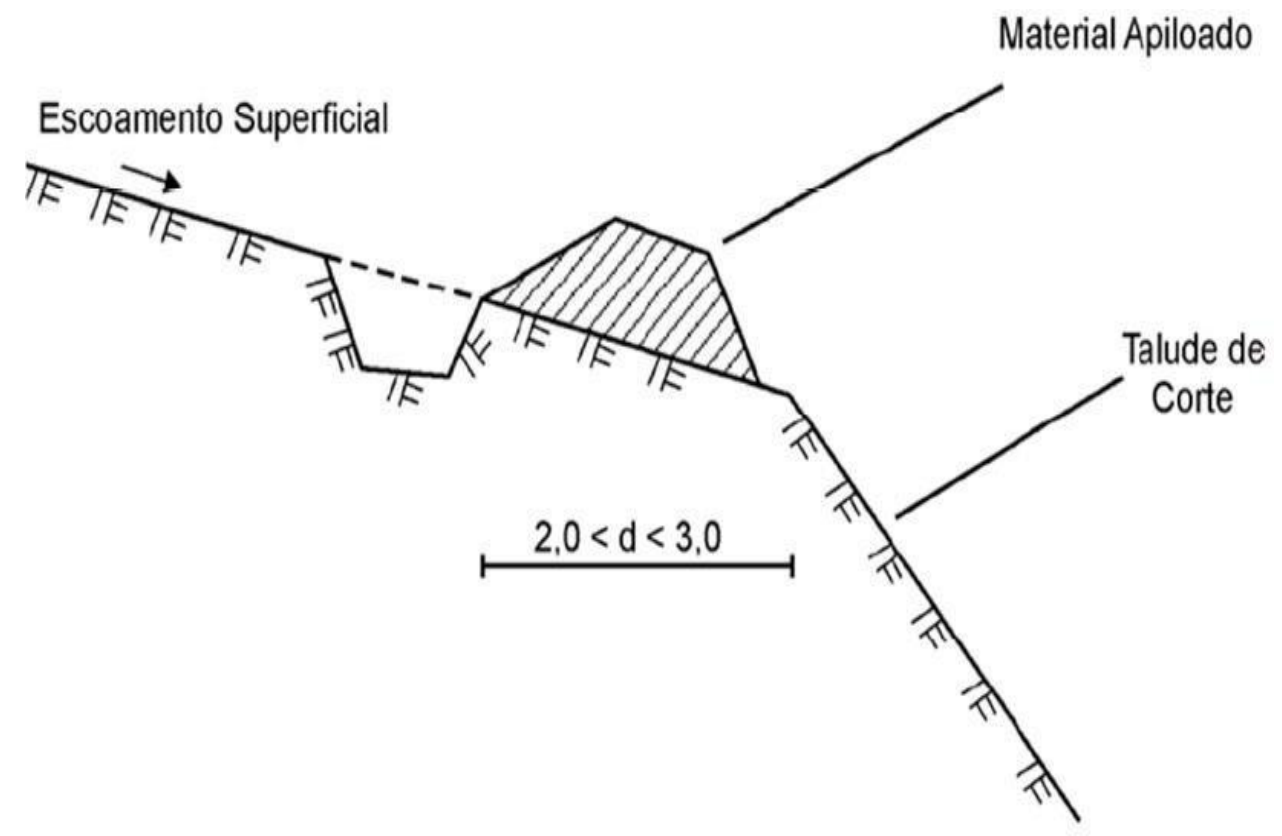

Fonte: Departamento Nacional de Infraestrutura de Transportes, 2006.

\subsubsection{Valetas de Proteção de Aterro}

Valetas de Proteção de Aterro (VPA) é semelhante a valeta de corte, consiste em um dispositivo destinado a interceptar e conduzir as águas precipitadas sobre as áreas próximas, e que escoam a montante dos aterros, tendo em vista impedir que atinjam a estrutura do pavimento (pé do aterro), conduzindo-as aos bueiros. Podem possuir seu revestimento de grama, pedra arrumada, pedra argamassada, concreto ou até mesmo o próprio solo compactado. Geralmente são construídas paralelamente ao pé do talude de 
aterro, a uma distância mínima entre $\mathrm{I}, \mathrm{o} \mathrm{m}$ da linha de offsets. Além disso, têm a finalidade de receber as águas provenientes das sarjetas e valetas de corte, conduzindo-as com segurança ao dispositivo de transposição de talvegues.

Imagem II. Valeta de proteção trapezoidal

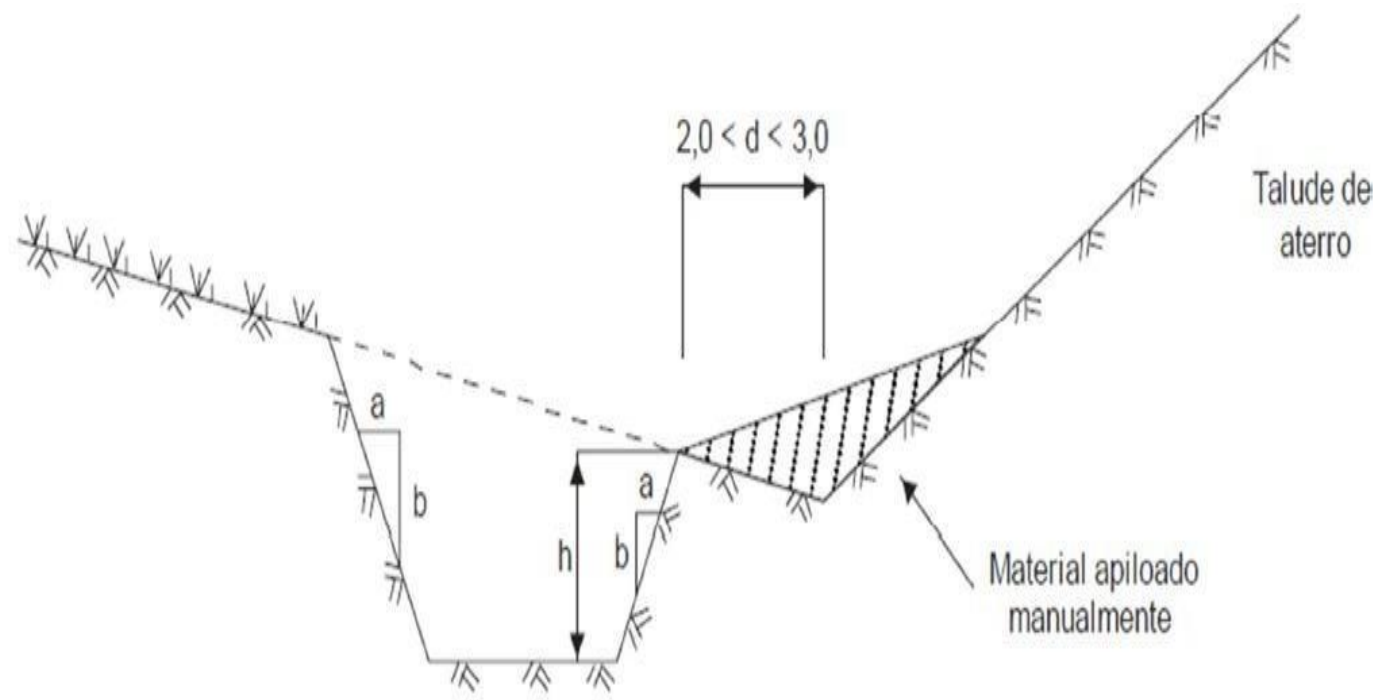

Fonte: Departamento Nacional de Infraestrutura de Transportes, 2006.

\section{I.9 Saídas d'Água}

As saídas d'água, também conhecida como entradas d'água são dispositivos destinados a conduzir as águas que são coletadas pelas sarjetas de aterro lançando-as nas descidas d'água. Portanto são dispositivos de transição entre as sarjetas de aterro e as descidas d'água. São localizados na borda da plataforma, juntamente aos acostamentos ou em alargamentos próprios para sua execução, nos pontos onde é atingido o comprimento crítico da sarjeta, nos pontos baixos das curvas verticais côncavas, junto às pontes, pontilhões e viadutos e, algumas vezes, nos pontos de passagem de corte para aterro. As saídas d'água devem possuir uma seção que permita uma rápida velocidade de captar as águas que escoam pela borda da plataforma que as conduz até as saídas d'água.

As descidas d'agua podem ter a seção de vazão das seguintes formas:

Retangular, em calha tipo rápido ou em degraus;

Semicircular ou meia cana, de concreto ou metálica; 
Em tubos de concreto ou metálicos (MANUAL DE DRENAGEM DO DNIT, 2006).

\section{Imagem I2. Vista saída d'água}

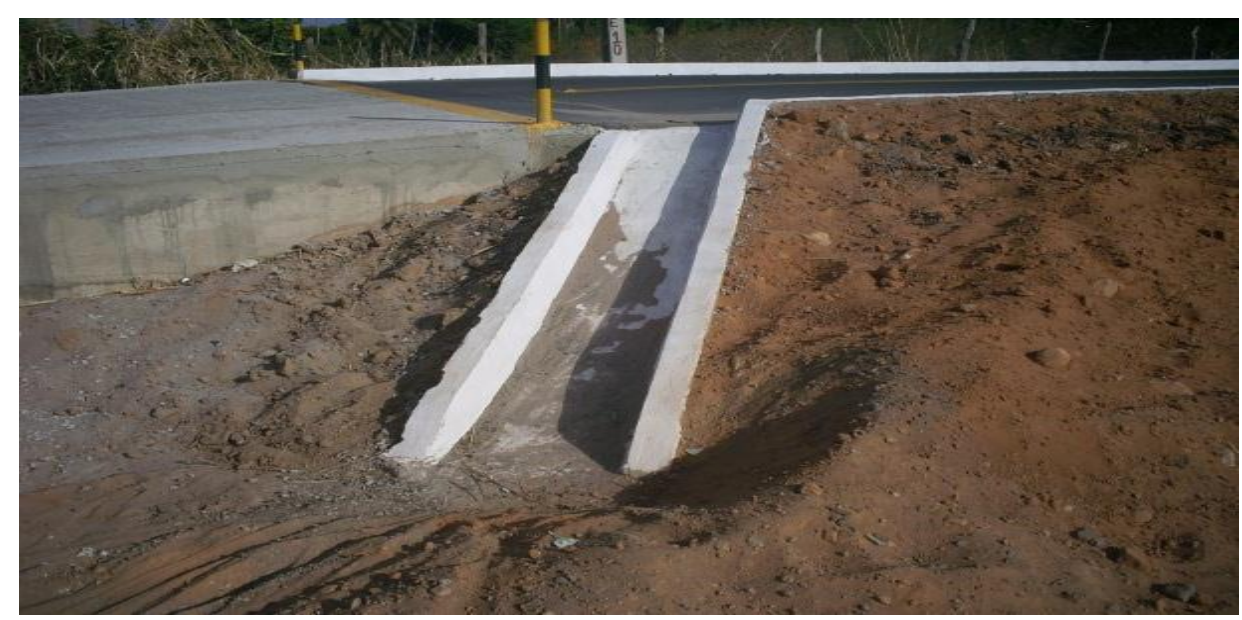

Fonte via: Disponível em $<$ https://cutt.ly/EnYLDEc $>$ Acesso em 04 de junho de 2021.

\section{1.ro Descidas d'Água}

É um dispositivo de sistema de drenagem transversal, tem como objetivo conduzir toda água captada de outros dispositivos de drenagem, através dos taludes de corte e aterro. Assim que atinge seu comprimento crítico, ou de pequenos talvegues, desagua na caixa coletora ou nas sarjetas de corte situadas na via, assim diminuindo a quantidade de água sobre a extensão da pista de rolamento.

Existem dois tipos de dispositivos de descidas d'água:

$>$ Rápida (lisa)

$>$ Em degraus.

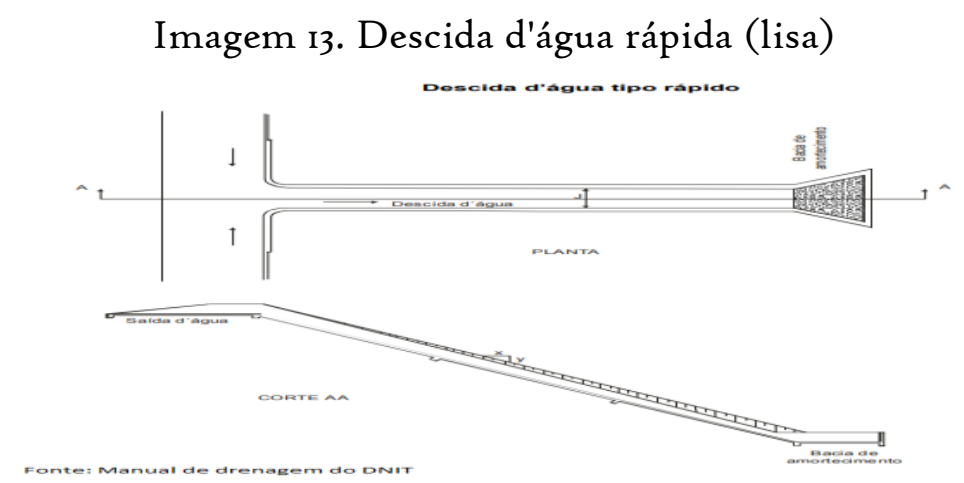

Fonte via: Disponível em< https://actionengenharia.net/2019/o5/o9/drenagem-superficial-descida-dagua/> Acesso em 04 de junho de 2021. 
Imagem i4. Descida d'água de corte em degraus

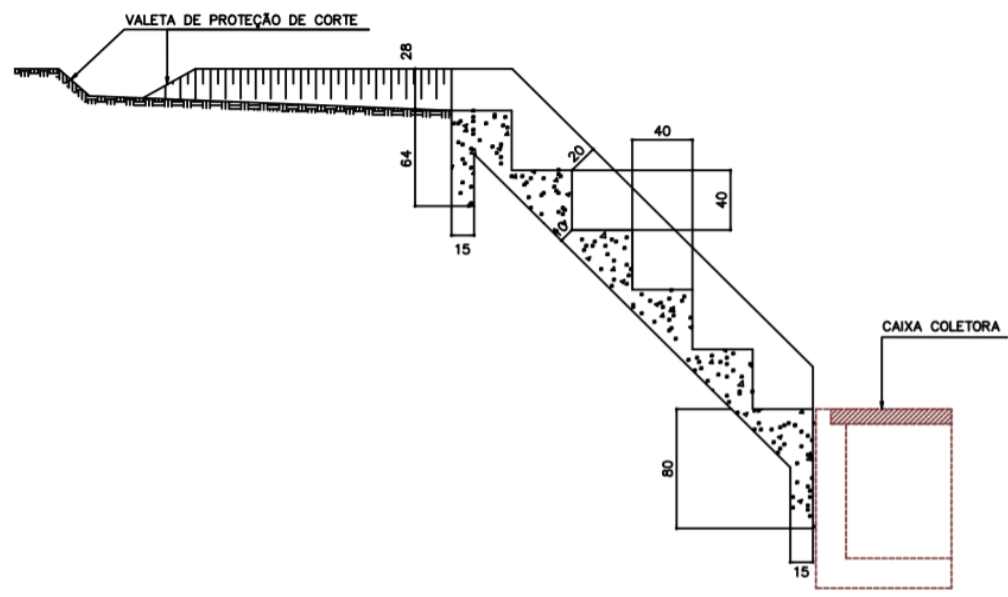

Fonte via: Disponível em< https://cutt.ly/mnYL9AZ > Acesso em os de junho de 202I.

\section{I.II Caixas Coletoras}

É um dispositivo responsável pelo armazenamento de águas provindas das sarjetas e das bocas de lobo fazendo ligação para as galerias.

Para que se tenha uma maior segurança, o recomendado é que seja construída afastada da borda da pista de rolamento, juntamente com uma grelha para a proteção do condutor que por acaso venha cair. A caixa coletora pode ter em média de até 2,50 $\mathrm{m}$ de altura para que possa facilitar a construção e manutenção da mesma.

Imagem 15. Caixa coletora

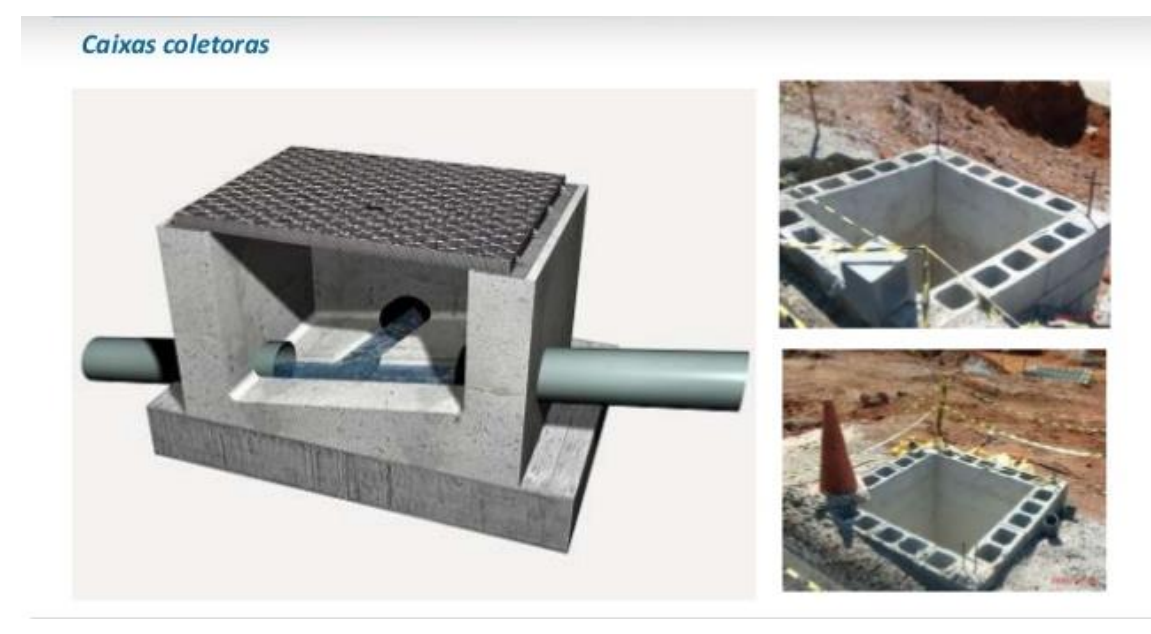

Fonte via: Disponível em< https://pt.slideshare.net/ivanrobertoa/drenagem-viria/> Acesso em os de junho de 2021. 


\subsubsection{Dissipadores de Energia}

Este dispositivo promove a dissipação do fluxo d'água reduzindo a velocidade, de modo que não haja risco de erosões no final das saídas d'água, descidas d'água, valetas de proteção e bueiros. O dissipador deve ser posicionado sempre no local de desague que seja adequado, caso contrário, o lançamento inapropriado pode acarretar sérios problemas ao meio ambiente.

Recomenda-se firmemente que sejam projetados e executados de forma a cumprir eficientemente seu papel, para que não cause erosões no solo e, por consequência, o assoreamento dos leitos dos rios e também a adulteração da qualidade da água.

Imagem i6. Dissipador de energia

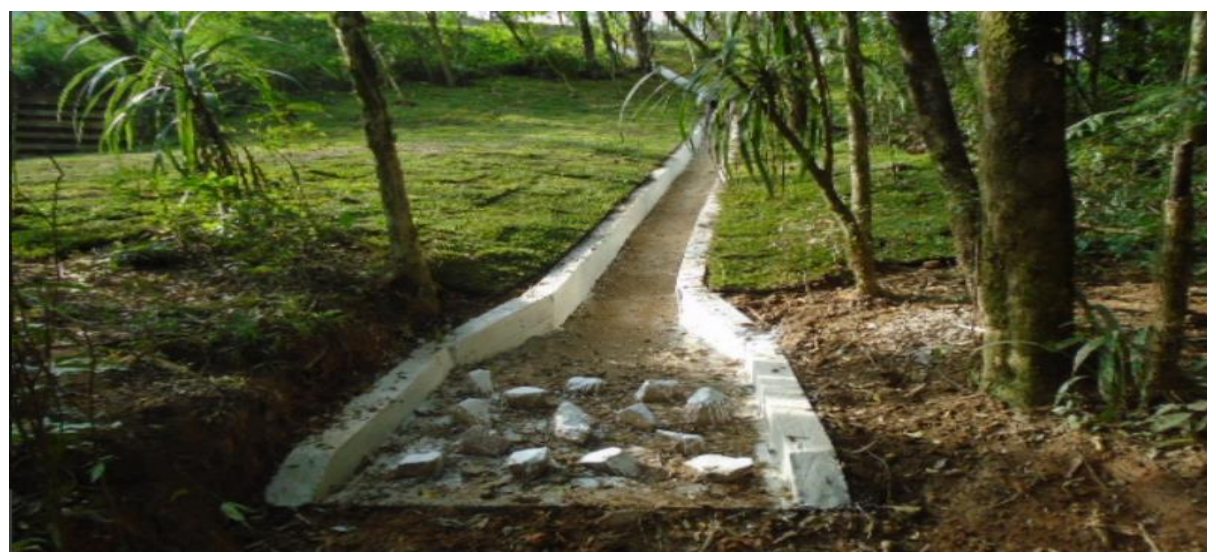

Fonte via: Disponível em< https://www.masterambiental.com.br/noticias/como-construir-pontes-commenos-impacto-ambiental//> Acesso em o6 de junho de 2021.

Imagem 17. Dissipador de energia em saída de bueiro como forma de contenção de

\section{processos erosivos}

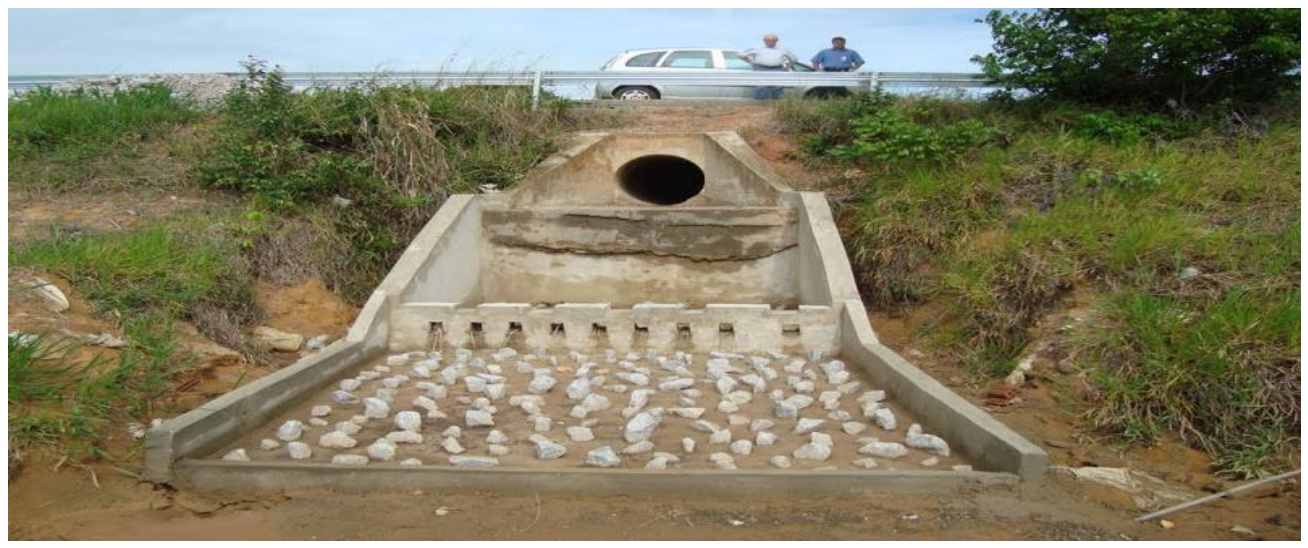

Fonte via: Disponível em<http://ampliarambiental.blogspot.com/2010/ı/supervisao-ambiental-na-br-1oIne-lotes_174.html//> Acesso em o6 de junho de 2021. 


\subsubsection{Corta Rios}

O corta-rio é um canal de desvio aberto com a função do encaminhamento da água ou evitar um curso d'água já existente, fazendo com que melhore a diretriz da rodovia. Após o final da execução da obra o curso d'água deve retornar ou seu leito original, ou seja, deve-se fazer a restauração do leito para sua condição inicial. Sua execução deve preferencialmente, ser implantado dentro da faixa de domínio.

Existem alguns procedimentos de controle ambiental referentes à proteção de corpos d'água, da vegetação lindeira e a segurança viária. Abaixo iremos evidenciar alguns cuidados e providências para a proteção do meio ambiente, a serem observados no decorrer da execução do corta rio.

O desmatamento e destocamento devem seguir rigorosamente os limites estabelecidos no projeto, ou pela fiscalização, evitando acréscimos desnecessários.

Nas operações de limpeza, a camada vegetal deve ser estocada, sempre que possível, para o futuro uso da recomposição vegetal da área escavada.

Não é permitida a queima do material vegetal removido.

O tráfego de equipamentos e veículos de serviço deve ser controlado para evitar a implantação de vias ou trilhas desnecessárias.

O material resultante da escavação deve ser depositado em local previamente autorizado pela fiscalização, para posterior recomposição da escavação.

O material escavado deve ser depositado e compactado com o tráfego dos equipamentos.

Deve ser executada drenagem da área de modo a evitar o carreamento do material para os corpos d'água.

O material deve ficar protegido contra intempéries com lonas ou vegetação. 
Imagem I8. Dispositivo Corta-rio

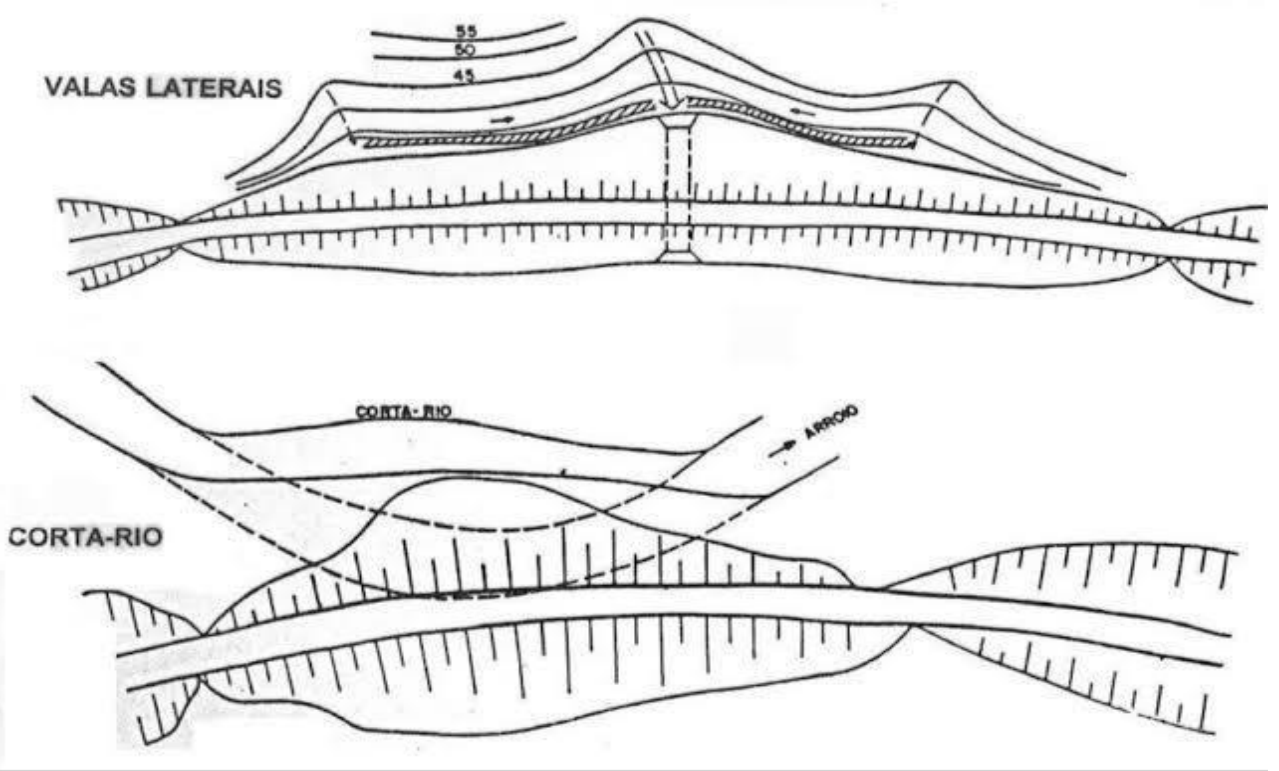

Fonte via: Disponível em< https://pt.slideshare.net/nataliaarauj03975/apostila-drenagem-2009> Acesso em o7 de junho de 202r.

\section{2 - DRENAGEM DE TRANSPOSIÇÃO DE TALVEGUES}

A principal função de um sistema de drenagem de uma rodovia é retirar toda e qualquer água que venha a atingir o corpo estradal, coletando-a e direcionando-a para locais que não prejudiquem a segurança e a durabilidade da via.

Em se tratando da transposição de talvegues, as águas advêm de uma bacia hidrográfica e devem ser atravessadas sem que comprometa a estrutura da estrada. A forma de execução é através de linhas de bueiros sob a construção de aterro ou construção de pontilhões, dessa forma traspondo o curso d'água, obstáculo a ser vencido pela rodovia.

\section{TIPOS DE DISPOSITIVOS UTILIZADOS}

$>$ Bueiros

$>$ Pontes

$>$ Pontilhões

Bueiros são obras de artes especiais que são designados a liberar a passagem livre das águas que percorrem as estradas. 


\section{OS BUEIROS PODEM SER CLASSIFICADOS EM QUATRO CLASSES:}

Quanto à forma da seção (tubulares, celulares, especial, elipses ou ovóides);

Quanto ao número de linhas (simples, duplos ou triplos);

$>$ Quanto aos materiais com os quais são construídos (tubos de concreto, tubos metálicos corrugados, células de concreto).

Bueiros simples é constituído por meio de uma única linha de dispositivo de escoamento.

Imagem 19. Bueiro simples tubular de concreto

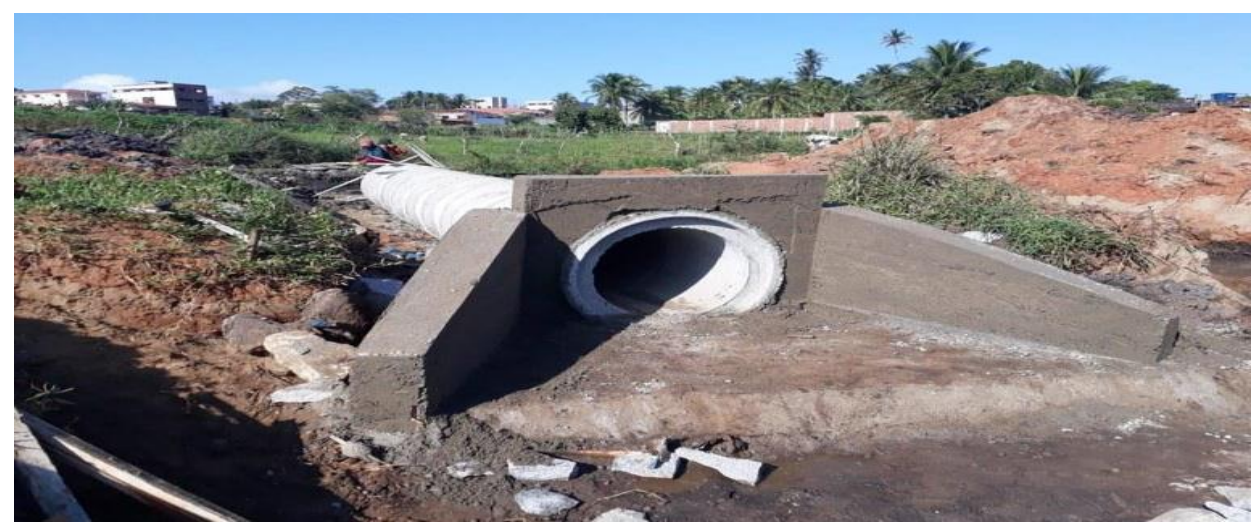

Fonte via: Disponível em< https://paraiba.pb.gov.br/noticias/governo-realiza-pavimentacao-de-rua-emitapororoca > Acesso em o7 de junho de 2021.

Bueiros duplos e triplos são constituídos por linha dupla e tripla de dispositivos de escoamento d’água

Imagem 2o. Bueiro duplo tubular de concreto

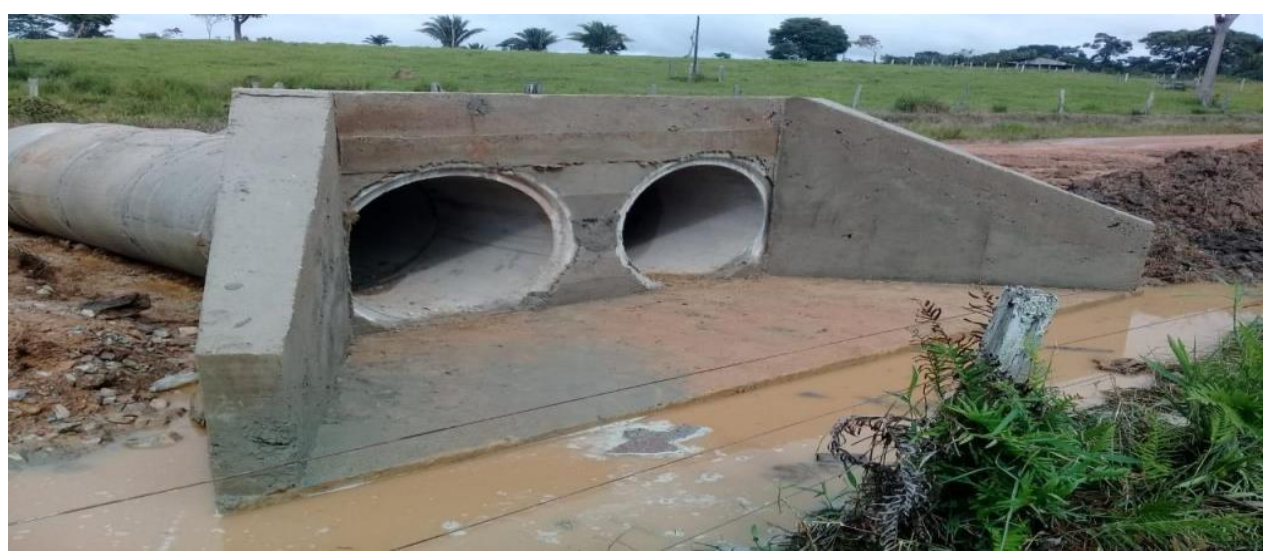

Fonte via: Disponível em< https://www.diariodaamazonia.com.br/prefeitura-instala-28-bueiros-na-linhauniao/> Acesso em o7 de junho de 202I. 
Imagem 2I. Bueiro triplo tubular de concreto

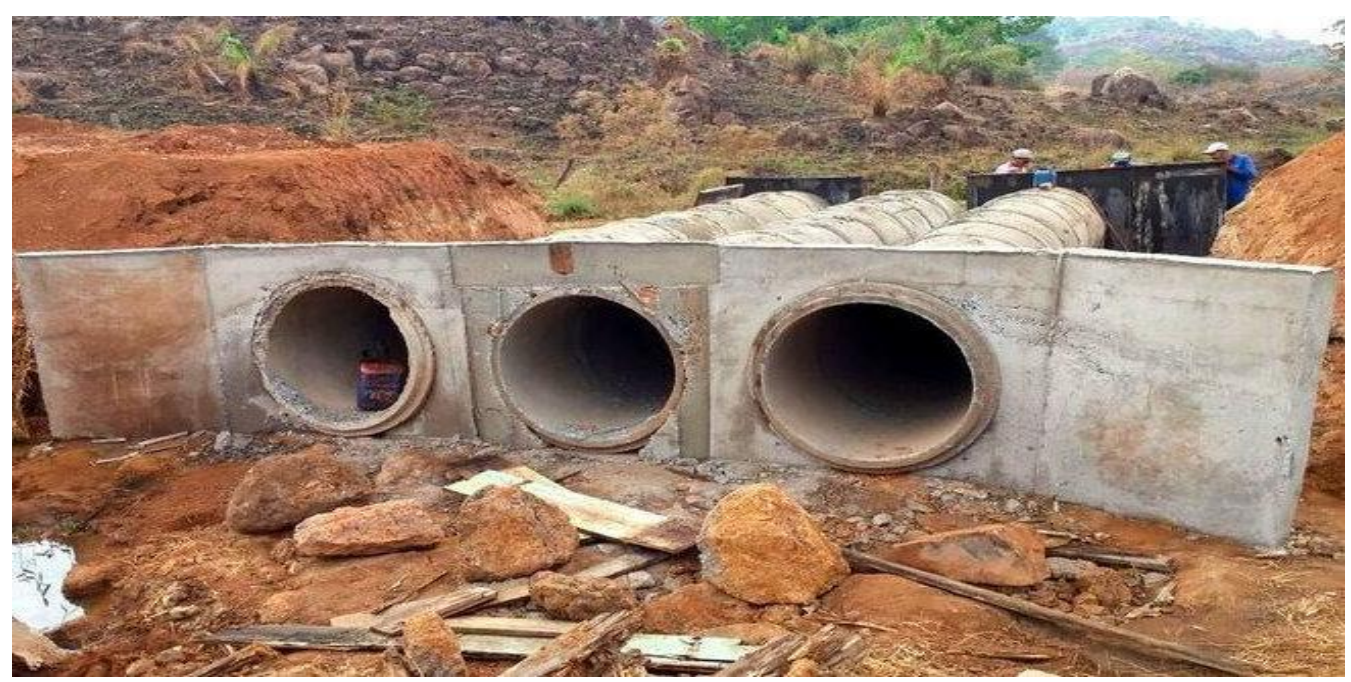

Fonte via: Disponível em< https://cutt.ly/UnYZGgF > Acesso em o7 de junho de 202r.

\section{BUEIRO CELULAR DE CONCRETO}

É um dispositivo constituído por células de concreto armado, com moldações in loco ou pré-moldados, este dispositivo tem por finalidade a transposição de córregos e riachos que são impedidos pela rodovia. Apresentam a seção quadrada ou retangular, sua execução pode ser em linhas simples, duplas ou triplas.

No quesito ambiental, quando construídos os bueiros devem ser preservadas as seguintes condições ambientais:

$>$ Todo o material excedente de escavação ou sobras deverá ser removido das proximidades dos dispositivos, evitando provocar o seu entupimento.

$>\mathrm{O}$ material excedente removido será transportado para local pré-definido em conjunto com a Fiscalização cuidando-se ainda para que este material não seja conduzido para os cursos d'água, de modo a não causar assoreamento.

$>$ Nos pontos de deságue dos dispositivos deverão ser executadas obras de proteção, para impedir a erosão das vertentes ou assoreamento de cursos d'água.

$>$ Durante o desenrolar das obras deverá ser evitado o tráfego desnecessário de equipamentos ou veículos por terrenos naturais, de modo a evitar a sua desfiguração. 
$>$ Caberá à Fiscalização definir, caso não previsto em projeto, ou alterar no projeto, o tipo de revestimento a adotar nos dispositivos implantados, em função das condições locais.

$>$ Além destas, deverão ser atendidas, no que couber, as recomendações da DNERISA o7- Instrução de Serviço Ambiental, referentes à captação, condução e despejo das águas superficiais ou subsuperficiais. (NORMA DNIT 025/2004).

Imagem 22. Bueiro celular de concreto

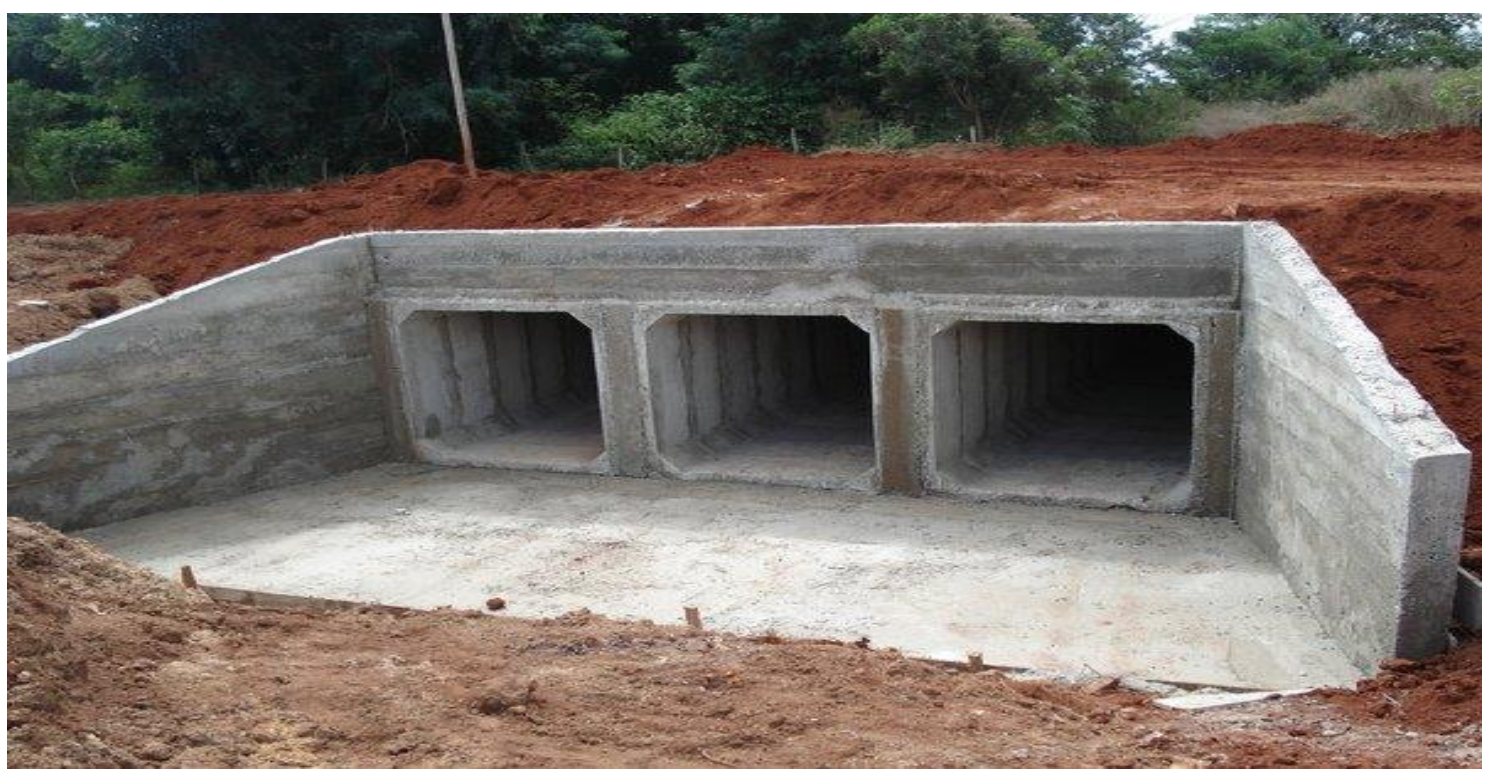

Fonte via: Disponível em< https://bityli.com/rLgdP > Acesso em o8 de junho de 2021.

\section{BUEIROS ESPECIAIS}

Imagem 23. Bueiro especial

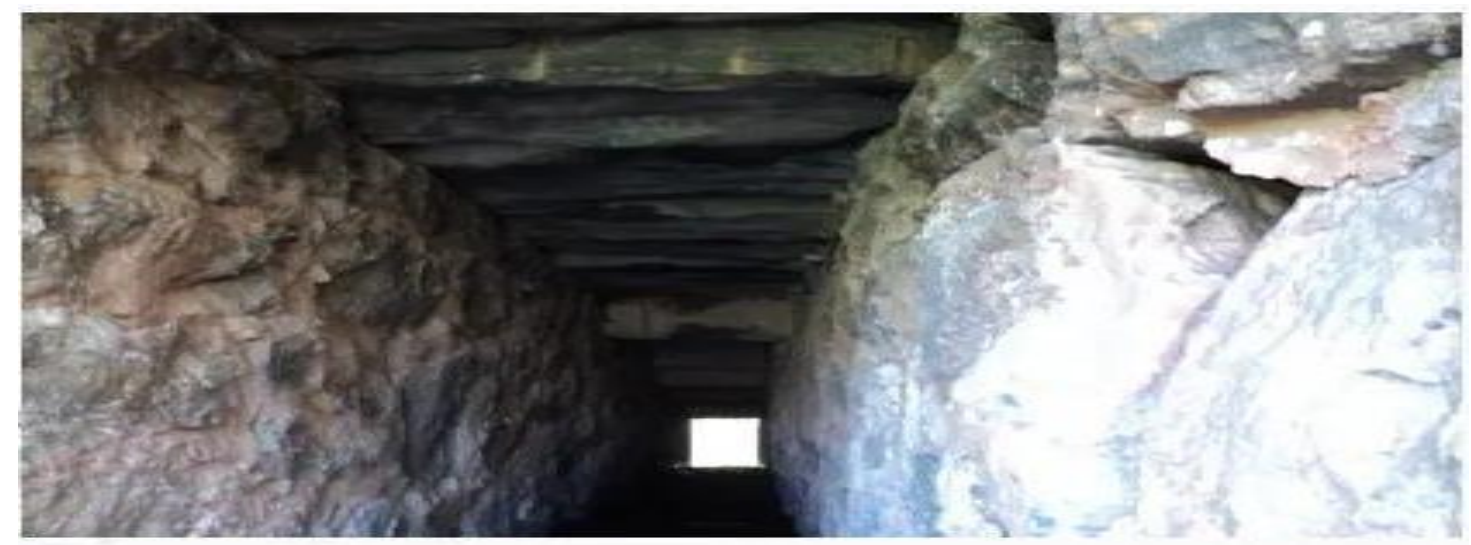

Fonte via: Disponível em< https://cutt.ly/RnYCwkq> Acesso em o9 de junho de 2021. 
São dispositivos constituídos por estruturas que podem ser de concreto, metálica ou alvenaria de pedra ou tijolos, podendo ter sua forma de arco, ovóides ou quadrada, retangular. Podendo ter suas respectivas dimensões variadas e suas aplicações mais específicas.

\section{3 - DRENAGEM DO PAVIMENTO OU SUBSUPERFICIAL}

Existem quatro técnicas de drenagem utilizadas:

I. Camada drenante

2. Drenos laterais de base

3. Drenos rasos longitudinais

4. Drenos transversais

\subsection{Camada drenante}

Todo projeto de sistema de drenagem rodoviária, preveem drenos subterrâneos para rebaixar o nível dos lençóis freáticos ressaltados. A drenagem subsuperficial tem por objetivo impedir as águas sobre a superfície da rodovia.

Há uma filosofia difundida no meio rodoviário, por partes dos técnicos, de que as infiltrações provenientes de chuvas ou de outras fontes superficiais não são críticas para a estrutura do pavimento. Com isto, raramente são previstos sistemas de drenagem com esta finalidade. Porém, outros autores, há tempos defendem a importância do sistema de drenagem subsuperficial como parte integrante de um projeto estrutural do pavimento. (HANNAH,2014).

As infiltrações de água ocorrem de duas formas: provenientes de água de chuva e também vindas dos lençóis freáticos subterrâneos. Estas ações danificam severamente a estrutura do pavimento caso a drenagem não suceder.

Imagem 24. Posicionamento das bases drenantes

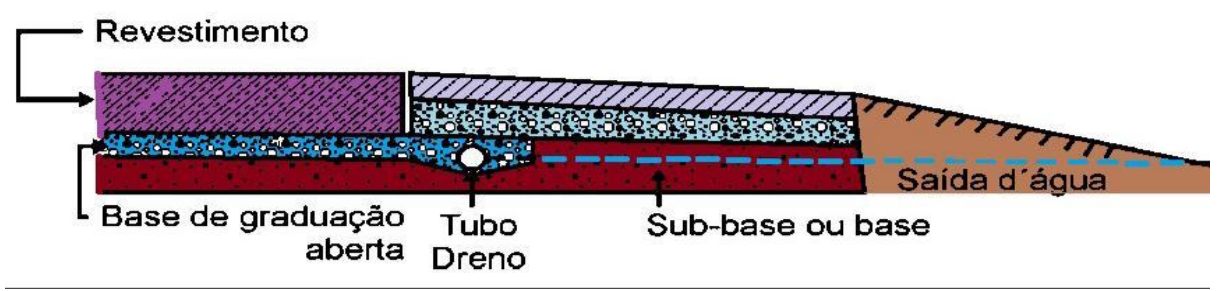

Fonte via: Disponível em< https://images.app.goo.gl/FiQpqeDXMgpEIvTv7> Acesso em o9 de junho de 2021. 


\subsubsection{Drenos laterais de base}

São dispositivos de drenos que possuem a mesma função dos drenos rasos longitudinais, ou seja, recolhe toda a água que foi drenada pela camada drenante, mas utiliza toda sua capacidade de escoamento da água. As águas drenadas percorrem juntamente a base dos acostamentos até findar toda a capacidade da camada drenante, por fim, quando forem capitadas pelos drenos laterais de base, serão eficazes hidraulicamente que as direciona-las para um lugar final seguro.

Imagem 25. Dreno subsuperficial de base

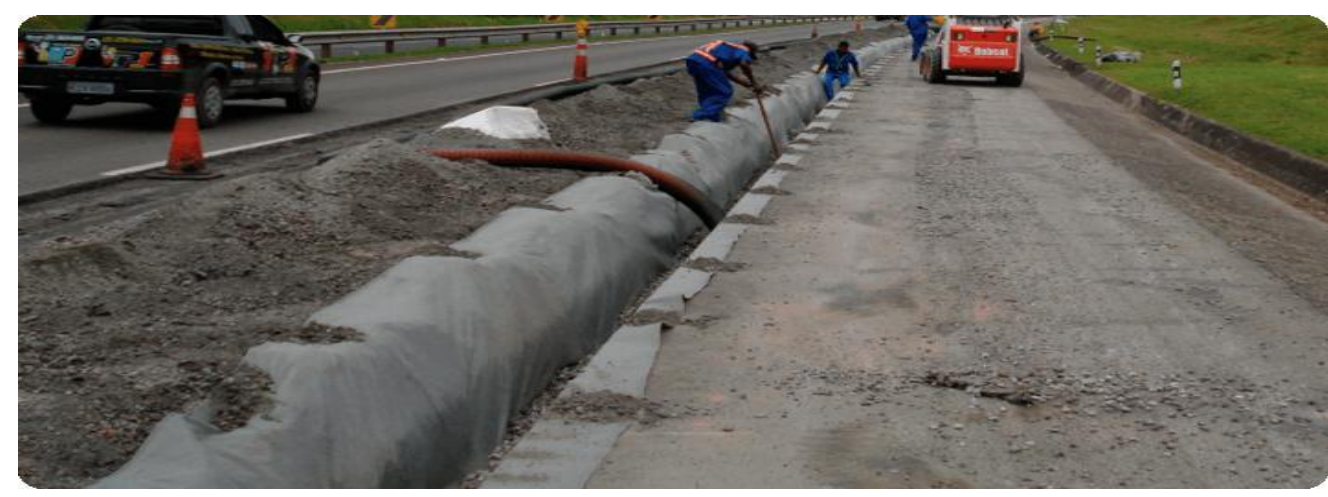

Fonte via: Disponível em< https://cutt.ly/JnY9KZ6> Acesso em o9 de junho de 202I.

\section{DRENOS RASOS LONGITUDINAIS}

Os dispositivos de drenos rasos longitudinais são responsáveis por receberem as águas que foram drenadas pela camada drenantes. A sua função primordial e coletar e realizar o direcionamento longitudinalmente águas infiltradas no pavimento, em áreas que possuem o confinamento lateral do pavimento por outros dispositivos como sarjetas e etc.

Imagem 26. Dreno raso longitudinal

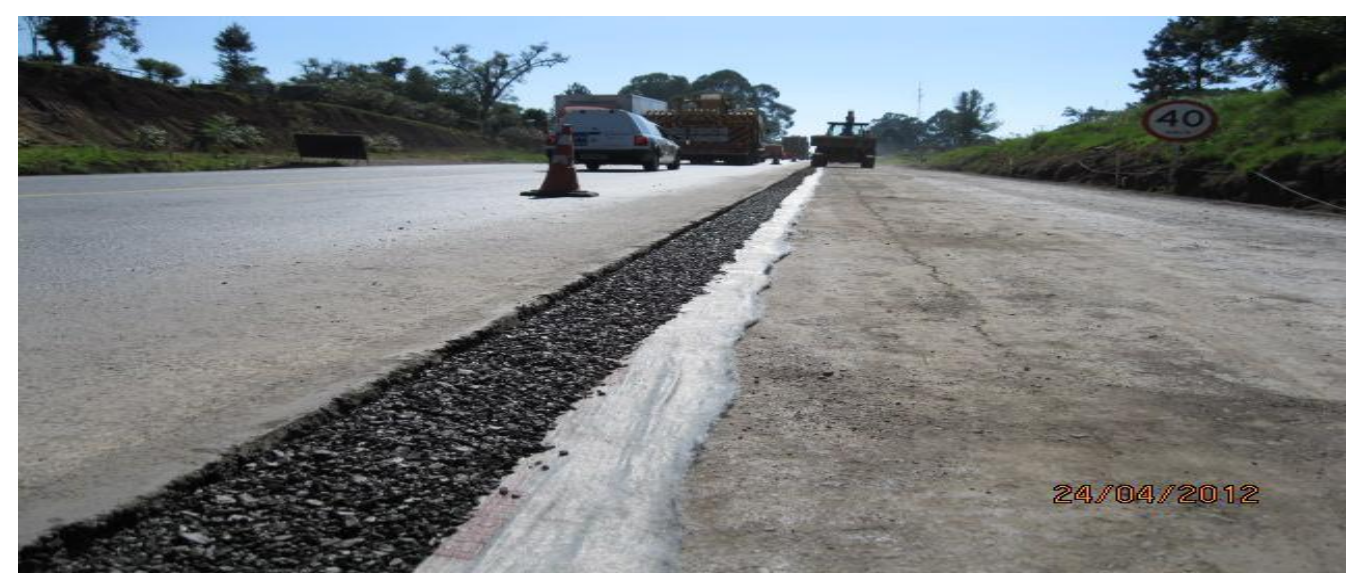

Fonte via: Disponível em< https://images.app.goo.gl/6LcLp5xSFpFLsCHY7> Acesso em II de junho de 202I. 


\section{DRENOS TRANSVERSAIS}

São dispositivos que tem como objetivo drenar as águas que transpõem as camadas do pavimento, ou suas interfaces longitudinalmente. São indicados para locais em pontos baixos das curvas verticais côncavas e em locais que se pretende drenar águas que por ventura foram acumuladas nas bases permeáveis, que não foram drenadas por outros dispositivos.

Estes drenos transversais tem sua projeção como drenos cegos, ou seja, sem tubos ou com tubo dreno que possuem ranhuras ou perfurações. Este tipo de drenos, assumem importante desempenho em relação a restauração das rodovias, onde houver abaixo do revestimento asfáltico uma base drenante sem o devido desague.

\section{CONSIDERAÇÕES FINAIS}

No discorrer desse artigo onde apresentamos alguns dos diversos tipos de dispositivos de drenagem, observamos que a água é a principal responsável em causar problemas no que se refere a rodovias e, que um sistema de drenagem bem projetado, construído e conservado, é muito importante para garantir a integridade da rodovia e aumentar a vida útil do pavimento da mesma.

Quando falamos de sistemas de drenagens recapitulamos que participam diversos tipos de dispositivos que visam, sobretudo, garantir a integridade tanto do corpo estradal e do seu entorno, quanto a segurança daqueles que transitam por elas.

Para que um sistema de drenagem viário implantado seja considerado eficaz, depende não somente de um bom projeto e construção adequada, mas também é de suma importância a manutenção desses dispositivos.

O sistema de drenagem superficial tem como objetivo evitar que essa água venha a danificar a plataforma e/ou atingir o corpo estradal. Portanto, são construídos dispositivos adequados que fazem a coleta da água e a conduzem para os seus canais naturais.

No que se refere às chuvas que caem diretamente sobre a pista de rolamento, devem ser tomadas providências que evitem sua acumulação ou infiltração. Uma das providências mais usuais é a adoção de declividades adequadas para a seção transversal. 
Compreender como funciona um sistema de drenagem requer conhecimentos básicos de hidrologia, estudos topográficos, bem como o projeto de drenagem em si e, evidentemente, os tipos de estruturas e métodos a serem utilizados.

Portanto, o presente artigo nos permitiu alcançar o objetivo principal que foi abordar de forma aprofundada alguns dos vários métodos disponíveis para a solução de problemas nos pavimentos rodoviários, sejam eles causados pela execução de um projeto mau dimensionado ou, até mesmo, a ausência de um.

\section{REFERÊNCIAS}

Brasil. Departamento Nacional de Estradas de Rodagem. Diretoria de Desenvolvimento Tecnológico. Divisão de Capacitação Tecnológica.

Diretrizes básicas para elaboração de estudos e projetos rodoviários (escopos básicos/instruções de serviço). - Rio de Janeiro, 1999.

375p. (IPR. Publ,. 707). Disponível em:

http://wwwi.dnit.gov.br/download/DiretrizesBasicas.pdf >. Acesso em: or de mar. 202I.

Projeto de Estradas. Disponível em:

http://professor.pucgoias.edu.br/SiteDocente/admin/arquivosUpload/ror39/material/aul ai.pdf $>$. Acesso em: or de mar. 2021

Drenagem de Rodovias e sua Importância para a Manutenção da Qualidade do Corpo Estradal

Disponível em:

https://docplayer.com.br/6552988o-Drenagem-de-rodovias-e-sua-importancia-para-amanutencao-da-qualidade-do-corpo-estradal.html>. Acesso em: 04 de abr. 2021

Drenagem de Rodovias. Disponível em: https://pt.scribd.com/doc/140173642/Drenagemde-Rodovias.pdf $>$. Acesso em: 02 de jun.202I.

Blog - Últimas notícias

Home / Noticias / Áreas Degradadas e Passivo Ambiental / 
Como construir pontes com menos impacto ambiental?

Disponível em:

https://www.masterambiental.com.br/noticias/como-construir-pontes-com-menosimpacto-ambiental/>. Acesso em: os de jun. 2021.

Agência Goiana de Transportes e Obras. AGETOP - ES-DRE Io/r8. DrenagemEspecificação Técnica - Corta-Rio.

Disponível em:

http://www.goinfra.go.gov.br/arquivos/arquivos/Normas/DRENAGEM/DRENAGE M_CORTA_RIO_ES_DRE_Io.pdf $>$. Acesso em: 06 de jun. 202I.

Sistemas de Drenagem em Pavimentos

Disponível em:

https://metalica.com.br/sistemas-de-drenagem-em-pavimentos-2/>. Acesso em: o9 de jun. 2021.

Drenagem Subsuperficial (Rasa). Disponível em: http://www.diprotec.com.br/solucao/drenos-subsuperficias/. Acesso em: II jun. 202I. 